\title{
Застосування методики імпедансної кардіографії при операціях коронарного шунтування на працюючому серці
}

\author{
Іоффе Н. О., Ящук К. В., Данилевська К. М., Руденко С. А., Витовський Р.М.
}

\author{
ДУ «Національний інститут серцево-судинної хірургії імені М. М. Амосова НАМН» (Київ)
}

\begin{abstract}
У Національному інституті серцево-судинної хірургії імені М. М. Амосова НАМН протягом останніх 15 років 95-97\% операцій коронарного шунтування виконуються на працюючому серці.

При операціях коронарного шунтування, що виконуються на працюючому серці, моніторинг гемодинаміки пацієнта є основним фактором забезпечення оптимальних умов для проведення оперативного втручання та профілактики виникнення інтраопераційних ускладнень, пов'язаних із незадовільною гемодинамікою пацієнта. Саме тому нами було впроваджено розширений моніторинг центральної гемодинаміки пацієнта із застосуванням методики імпедансної кардіографії, що дає можливість передбачити та вчасно скорегувати порушення гемодинаміки пацієнтів на різних етапах операції.

Мета роботи - визначити можливості застосування методики імпедансної кардіографії для оцінки системної гемодинаміки у пацієнтів під час проведення операції коронарного шунтування на працюючому серці.
\end{abstract}

Ключові слова: імпедансна кардіографія, коронарне шунтування на пращюючому серці, серцевий індекс.

У Національному інституті серцево-судинної хірургії імені М. М. Амосова НАМН України протягом останніх 15 років 95-97\% операцій коронарного шунтування виконуються на працюючому серці [1].

При операціях коронарного шунтування, що виконуються на працюючому серці, моніторинг гемодинаміки пацієнта $є$ основним фактором забезпечення оптимальних умов проведення оперативного втручання та профілактики виникнення інтраопераційних ускладнень, пов'язаних із незадовільною гемодинамікою пацієнта. Саме тому нами було впроваджено розширений моніторинг центральної гемодинаміки пацієнта із застосуванням методики імпедансної кардіографії (ІКГ), що дає можливість передбачити та вчасно скорегувати порушення гемодинаміки пацієнтів на різних етапах операції [2].

Методики визначення серцевого індексу пацієнта можна розділити на дві групи - інвазивні та неінвазивні. До інвазивних методик належать метод термодилюції, що здійснюється за допомогою катетера Swan-Ganz, і метод PICCO, який поєднує методику транспульмональної термодилюції та оцінку пульсової хвилі. До неінвазивних методик визначення серцевого індексу належать пульсоксиметрична методика, що розраховується на основі оцінки пульсоксиметрії та сигналу ЕКГ, імпедансна кардіографія, яка базується на визначенні імпедансної хвилі, утворюваної при зміні об’єму та швидкості крові в аорті протягом одного серцевого циклу, що є причиною зміни грудного опору. Цей сигнал використовують для розрахунку ключових гемодинамічних параметрів за допомогою новітніх математичних алгоритмів розрахунку [3].
Безумовно, інвазивні методики визначення серцевого індексу є золотим стандартом і показують високу точність результатів та широкий спектр обчислюваних параметрів. Проте неінвазивні методики, до яких належить ІКГ, на сьогоднішній день широко використовуються у практичній медицині при діагностиці серцевої недостатності, у пацієнтів із артеріальною та легеневою гіпертензією (методика була застосована для обстеження льотчиків, альпіністів, а також робітників заводів з метою дослідження впливу на організм шкідливих умов праці) [4]. За даними літератури, при порівнянні з іншими неінвазивними методиками та ехокардіографією методика IКГ зарекомендувала себе як точний і простий у використанні спосіб визначення показників гемодинаміки [5], а також як методика, що не має протипоказань до застосування і може бути використана для повсякденної роботи в операційній та у відділенні інтенсивної терапії.

Опишемо спосіб використання методики ІКГ. На шию та грудну клітку обстежуваного пацієнта (рис. 1) накладають 8 електродів симетрично із правого та лівого боків. Електроди, розташовані з лівого боку, називають внутрішніми: вони вимірюють електричний імпеданс, який виникає при скороченні серця. Електроди, розташовані з правого боку, є зовнішніми електродами, за якими оцінюється швидкість проведення електричного імпедансу [6].

Методика IКГ дає можливість визначити такі показники гемодинаміки: ударний об’єм (УО), індекс ударного об'єму (ІУО), серцевий викид (СВ), індекс серцевого викиду (ICB), системний судинний опір (CCO), індекс системного судинного опору (ICCO). 


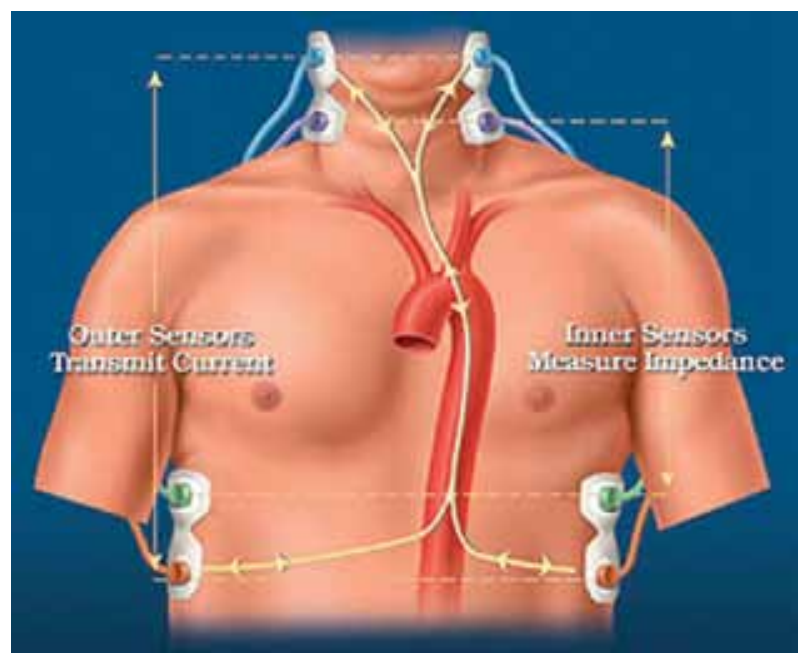

Рис. 1. Методика використання електродів ІКГ

Серцевий викид - це об’єм крові, що перекачує серце за одну хвилину, він складається з ударного об’єму, помноженого на частоту серцевих скорочень (ЧСС). Серцевий викид, поділений на площу поверхні тіла, $€$ серцевим індексом (CI). Величина серцевого індексу залежить від переднавантаження, постнавантаження та скорочувальної здатності міокарда [7].

Мета роботи - визначити можливості застосування методики імпедансної кардіографії для оцінки системної гемодинаміки у пацієнтів під час проведення операції коронарного шунтування на працюючому серці.

Матеріали та методи. Нами обстежено 50 пацієнтів, яким було виконано операцію коронарного шунтування на працюючому серці в ДУ «Національний інститут серцево-судинної хірургії імені М. М. Амосова» починаючи із грудня по липень 2017 року.

Характеристика пацієнтів. Середній вік обстежених нами пацієнтів на момент операції становив $65 \pm 10$ років. Осіб чоловічої статі було 46 (92\%), жіночої - 4 (8\%). Середня маса тіла дорівнювала $75 \pm 9$ кг, середній зріст $-170 \pm 25$ см, середня площа поверхні тіла становила $1,97 \pm 0,9 \mathrm{M}^{2}$.

$30(60 \%)$ обстежених нами пацієнтів мали в анамнезі інфаркт міокарда (IM), 4 (8\%) пацієнти - два інфаркти. Супутніми захворюваннями були гіпертонічна хвороба $(Г Х)$, діагностована у 35 (70\%) пацієнтів, цукровий діабет (ЦД) - у 5 (10\%), хронічне обструктивне захворювання легень (ХОЗЛ) - у 4 (8\%), гостре порушення мозкового кровообігу (ГПМК) - у 1 (2\%) пацієнта.

Усім пацієнтам перед операцією було виконано стандартне обстеження 3 використанням клінічних, лабораторних та інструментальних (рентгенографія органів грудної клітки, ЕКГ, ЕхоКГ, коронаровентрикулографія) методів обстеження.

Результати, отримані нами при порівнянні методики ІКГ із методикою зовнішньої трансторакальної ехографії на початку операції, наведено в табл. 2.

\section{Таблиця 1}

Характеристика обстежених пацієнтів

\begin{tabular}{|c|c|c|}
\hline $\begin{array}{l}\text { Нозологічна } \\
\text { форма }\end{array}$ & $\begin{array}{l}\text { Кількість пацієнтів } \\
\text { (n) }\end{array}$ & $\begin{array}{c}\text { Відсоток пацієнтів } \\
\text { (\%) }\end{array}$ \\
\hline IM & 30 & 60 \\
\hline$\Gamma X$ & 35 & 70 \\
\hline ЦД & 5 & 10 \\
\hline ХОЗл & 4 & 8 \\
\hline ГПМК & 1 & 2 \\
\hline
\end{tabular}

\section{Таблиця 2}

Характеристика обстежених хворих за даними ЕхоКГ

\begin{tabular}{lccc} 
Показник & $\begin{array}{c}\text { Мінімальне } \\
\text { значення }\end{array}$ & $\begin{array}{c}\text { Максимальне } \\
\text { значення }\end{array}$ & $\begin{array}{c}\text { Середнє } \\
\text { значення }\end{array}$ \\
\hline $\mathrm{КДО,} \mathrm{cm}^{3}$ & 104 & 230 & $163 \pm 38$ \\
\hline $\mathrm{KCO}, \mathrm{cm}^{3}$ & 40 & 138 & $79 \pm 33$ \\
\hline $\mathrm{УO}, \mathrm{CM}^{3}$ & 59 & 124 & $81 \pm 13$ \\
\hline$Ф В, \%$ & 40 & 70 & $54 \pm 9,7$
\end{tabular}

Інтраопераційний моніторинг гемодинаміки здійснювався за допомогою монітору фірми UTAS моделі UM300 з адаптованим до нього модулем ICG. До початку операції кожному з обстежуваних нами пацієнтів приєднували електроди для реєстрації показників ICG, 5 електродів для реєстрації ЕКГ, на монітор виводили криву артеріального тиску, зареєстровану прямим методом вимірювання, а також показник центрального венозного тиску. Для обчислення індексу доставки кисню вводили показник гемоглобіну кожного пацієнта та його антропометричні дані. Таким чином, до початку операції мали показники гемодинаміки кожного пацієнта, як показано на фото 1.

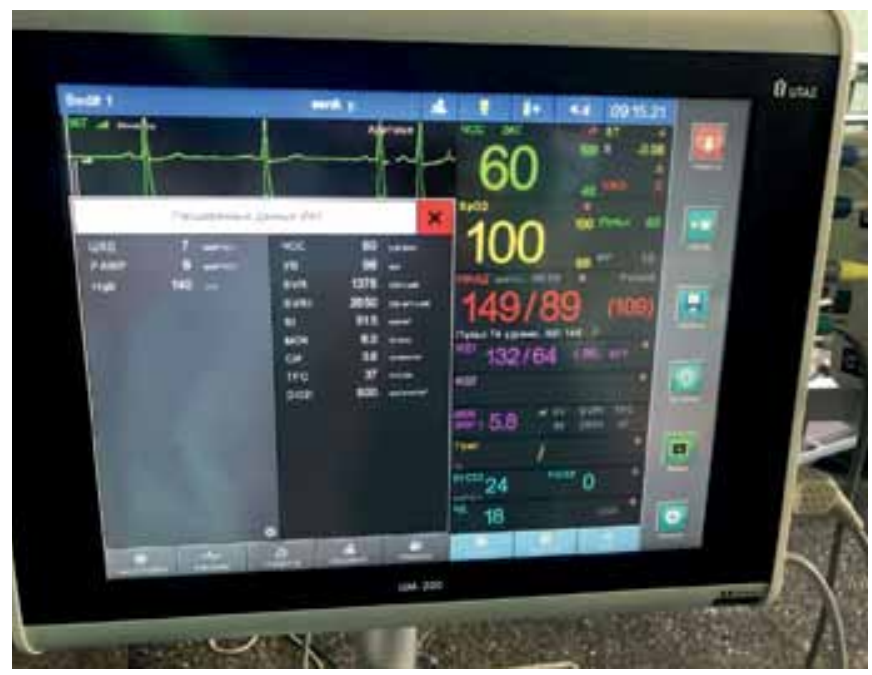

Фото 1. Показники гемодинаміки пацієнта 


\section{Таблиця 3}

Показники гемодинаміки протягом операції

\begin{tabular}{lc} 
Показник & Середнє значення \\
\hline АТС, мм рт. ст. & $144,5 \pm 21,09$ \\
\hline АТд, мм рт. Ст. & $77,1 \pm 11,6$ \\
\hline ЧСС, уд./Хв. & $69,5 \pm 8,8$ \\
\hline ЦВТ, мм вод. ст. & $47,6 \pm 10,1$ \\
\hline $\mathrm{CO}_{2}$, мм рт. ст. & $28,7 \pm 3,67$ \\
\hline $\mathrm{SpO}_{2}, \%$ & $98,9 \pm 1,5$
\end{tabular}

\section{Таблиця 4}

Показники центральної гемодинаміки, зареєстровані методикою ІКГ

\begin{tabular}{|c|c|}
\hline Показник & Середнє значення \\
\hline $\mathrm{Cl}, \pi /$ Хв./M ${ }^{2}$ & $3,9 \pm 1,34$ \\
\hline УО, мл & $96,4 \pm 28,7$ \\
\hline $\mathrm{IVO}, \mathrm{M} / \mathrm{M}^{2}$ & $47,25 \pm 9,9$ \\
\hline $\mathrm{CCO}, \mathrm{DS} / \mathrm{CM}^{5}$ & $1237,14 \pm 328,8$ \\
\hline ICCO, DSM ${ }^{3} / \mathrm{CM}^{5}$ & $2462 \pm 575,5$ \\
\hline ДО, & $617,1 \pm 160,6$ \\
\hline
\end{tabular}

Результати та обговорення. В обстежених нами пацієнтів протягом операції коронарного шунтування на працюючому серці були визначені такі показники гемодинаміки: систолічний артеріальний тиск (ATc) $144,5 \pm 21,09$, діастолічний артеріальний тиск (АТд) $77,1 \pm 11,6$, частота серцевих скорочень - 69,5 $\pm 8,8$, центральний венозний тиск (ЦВТ) $47,6 \pm 10,1$, концентрація вуглекислого газу $\left(\mathrm{CO}_{2}\right)-28,7 \pm 3,67$ та сатурації крові $\left(\mathrm{SpO}_{2}\right)-98,9 \pm 1,5$.

За допомогою методики імпедансної кардіографії протягом операції коронарного шунтування нами було визначено такі показники центральної гемодинаміки: серцевий індекс, середня величина якого дорівнювала $3,9 \pm 1,34$, ударний об’єм - 96,4 28,7 , індекс ударного об'єму - 47,25 $\pm 9,9$, системний судинний опір - $1237,14 \pm 328,8$, індекс системного судинного опору - 2462 $\pm 575,5$, показник доставки кисню $\left(\right.$ ДО $\left._{2}\right)$ $-617,1 \pm 160,6$.

Висновки. Методика IКГ, застосована нами у пацієнтів під час операцій коронарного шунтування на працюючому серці, дає можливість оцінити вихідні показники гемодинаміки у пацієнтів із IXC, оцінити рівень волемічного навантаження пацієнтів, а також визначити рівень серцевого викиду та серцевого індексу в пацієнтів з IXC, дослідити його динаміку протягом операції та на основі визначених параметрів своєчасно призначити лікування для корекції гемодинамічних змін.

\section{Література}

1. Руденко А. В., Журба О. А. Аортокоронарне шунтування на працюючому серці: плановий та екстрений перехід на штучний кровообіг // Вісник серцево-судинної хірургії. -2015 . - Вип. 23.

2. 10 тысяч операций коронарного шунтирования на работающем сердце (опыт одной клиники) / Руденко А. В., Урсуленко В. И., Купчинский А. В. // Вісник серцево-судинної хірургії. - 2016. - Вип. 1.

3. Risk factors for decreased cardiac output after coronary artery bypass grafting: a prospective cohort study / Dos Santos E. R., Lopes C. T., Maria V. L. et al. // Eur J Cardiovasc Nurs. - 2016 Nov 25. pii: 1474515116681373. [Epub ahead of print]

4. Design and Implementation of a Portable Impedance Cardiography System for Noninvasive Stroke Volume Monitoring / Yazdanian H., Mahnam A., Edrisi M. et al. |// J Med Signals Sens. - 2016 Jan-Mar. - Vol. 6 (1). P. 47-56.

5. Validation of impedance cardiography in pulmonary arterial hypertension / Panagiotou M., Vogiatzis I., Jayasekera G. et al. |// Clin Physiol Funct Imaging. - 2017 Feb 6. doi: 10.1111/cpf.12408. [Epub ahead of print]

6. Comparison of bioreactance non-invasive cardiac output measurements with cardiac magnetic resonance imaging / Trinkmann F., Schneider C., Michels J. D. et al. |// Anaesth Intensive Care. - 2016 Nov. - Vol. 44 (6). - P. 769-776.

7. Biological variation of the cardiac index in patients with stable chronic heart failure: inert gas rebreathing compared with impedance cardiography / Tдger T., Frцhlich H., Franke J. et al. |// ESC Heart Fail. - 2015 Sep. - Vol. 2 (3). - P. 112-120.

8. Cardiac stroke volume variability measured non-invasively by three methods for detection of central hypovolemia in healthy humans / Holme N. L., Rein E. B., Elstad M. et al. |// Eur J Appl Physiol. - 2016 Dec. - Vol. 116 (1112). - P. 2187-2196.

9. Evaluation of Impedance Cardiography for Measurement of Stroke Volume in Congenital Heart Disease / Ebrahim M., Hegde S., Printz B. et al. |// Pediatr Cardiol. - 2016 Dec. Vol. 37 (8). - P. 1453-1457. 


\title{
Using the method of impedance cardiography in cases Off-pump coronary artery bypass graft (CABG) surgery
}

\author{
loffe N., Yaschuk K., Danilevskaya K., Rudenko S., Vitovsky R. \\ National M. M. Amosov Institute of Cardiovascular Surgery National Academy of Medical Sciences of Ukraine
}

The data on impedance cardiography, its diagnostic value and possible different applications suggest that it may also be very useful in cases Off-pump coronary artery bypass graft (CABG) surgery.

Impedance cardiography is non-invasive, which is of a particular advantage over the conventional methods that require catheterization. As a result, the patient is not at risk of possible complications and the procedure is less expensive. The test involves placing, on the skin of the patient, the output electrodes to apply high-frequency low-intensity alternating current to the patient's chest, and the receiving electrodes to record voltage variations and obtain electrocardiography (ECG) recording.

Various authors report that attempts have been continued to compare the results from ICG and those obtained by other diagnostic methods.

In cases Off-pump coronary artery bypass graft $(\mathrm{CABG})$ surgery Impedance cardiography is good opportunity to establish hemodinamics, manage the fluid level a patient, trend and detect hemodynamic changes during the operation.

Key words: impedance cardiography, cardiac output, Off-pump coronary artery bypass graft (CABG) surgery.

\section{Применение методики импедансной кардиографии при операциях коронарного шунтирования на работающем сердце}

\author{
Иоффе Н. А., Ящук К. В., Данилевская К. М., Руденко С. А., Витовський Р. М. \\ ГУ «Национальный институт сердечно-сосудистой хирургии имени Н. М. Амосова НАМН» (Киев)
}

В Национальном институте сердечно-сосудистой хирургии имени Н. М. Амосова НАМН в течение последних 15 лет 95-97\% операций коронарного шунтирования выполняются на работающем сердце.

При операциях коронарного шунтирования, выполняемых на работающем сердце, мониторинг гемодинамики пациента является основным фактором обеспечения оптимальных условий для проведения оперативного вмешательства и профилактики возникновения интраоперационных осложнений, связанных с неудовлетворительной гемодинамикой пациента. Именно поэтому нами был введен расширенный мониторинг центральной гемодинамики пациента с применением методики импедансной кардиографии (ИКГ), что дает возможность предусмотреть и вовремя скорректировать нарушения гемодинамики пациентов на разных этапах операции.

Цель работы - определить возможности применения методики импедансной кардиографии (ИКГ) для оценки системы гемодинамики у пациентов во время проведения операции коронарного шунтирования на работающем сердце.

Ключевые слова: импедансная кардиография, коронарное шунтирование на работающем сердие, сердечный индекс. 